\title{
Women and Development in India: An issue of marginalization of female labour
}

\author{
Dr. Sriparna Guha \\ Department of Business Administration, Narula Institute of Technology
}

\begin{abstract}
In most of the countries, including India status of women is inferior to men. Women's opportunities are said to be restricted by ideas among employers that only certain low level limited jobs can be performed by women. Women are thus said to be crowded into certain segments of the employment markets where wages and conditions are lower than their male counterparts. This situation aggravated due to the pressure of globalization. This phenomenon can be called marginalization of female labour". Although rapid economic development has expanded women's job opportunities, most women are concentrated in lower-status jobs and the informal sector. Indian women, in spite of enjoying better status and position compared to other developing countries, have low levels of participation in economic activity. In such setting, this study aims to take a fresh look at the current situation of gender equality in the labour market in India and examine the trend of women's employment status using both macro and micro level data and finally evaluates the effects of employment on economic independence relative to men. In the micro-level analysis the study examines the factors that led to the marginalization of women's labor force. The results suggest that women's work patterns in terms of formal $v$ s. informal employment are determined by the family organization rather than by labor market .
\end{abstract}

Key words: employment, empowerment, gender, globalization, marginalization

\section{Introduction}

Throughout the world participation of women in labourforce are increasing. Though women have increased their participation in technology but that participation is still below their counterparts. Professional work is one of societies' most contested areas of equality. The rise of professional projects is closely linked to power and occupational control which parallel gender, class and race clevages (Parry and Parry,1976). Now -adays most important question is no longer whether women participate in labourforce but most important questions are what types of careers women choose and what factors influence their choice in the light of evidence that women are found in what could be describe (d) as "feminine" occupations . Different research works have tried to identify the beliefs and perceptual biases that can lead to faulty conclusions about an individual and social action. From the study of Stangor,(1988) it has been found that gender stereotypes lie at the heart of many of our perceptions of the workplace and the people that operate within it. The constellation of traits and attributes that are thought to uniquely describe men and women are called descriptive stereotypes. These stereotypes are applied to individuals that one encounters in work settings and become the basis for inferring their internal, stable characteristics. Thus even in situations in which person A may have very little knowledge about person B, he or she will infer a set of characteristics about A from the general category of man or woman to which person B belongs .In contrast to descriptive stereotypes, prescriptive stereotypes refer to the set of attributes and characteristics that (concentrates on the issue of) how men and women should be. This paper attempts to analyse the current situation of gender equality in the Indian labour market and examine the trend of women's employment status. The structure of the paper is as follows: besides the introduction, section II will give the review of related literature, Section -III deals with secondary data and analyses the status of women and their threats and opportunities in the current economy, finally Section-IV gives conclusion from the data analysis and suggestion.

\section{Review Of Literature}

In a study of Gladmin \& Thompson (1995) a significant increase in the quality of women life related with their income rise (has been found) in case of developing countries. It is echoed with Amartya Sen's freedom perspective that economic unfreedom can breed social unfreedom.

According to Standing (1996) in the process of globalization with an expansion of the export oriented sector has introduces grater flexibility to the benefit of women workers in terms of absorption of women into paid work and also shift in the gender differentiated structure of occupations. But these views have been contradicted by other scholars who argue that in spite of increase in women employment the labour market remain highly segregated.

According to Stiglitz (2002), it is believed that globalization is not increasing the well being for those most in need of promised economic benefit. 
In a study consisting of 40 countries it is found that women are employed in a narrow range of industries while men spread over a wider array of occupation (Anker,1998) Berk (1985) suggests that the persistence of women's responsibility for the domestic sphere arises because couples "do" gender. Couples "do" gender to legitimate social arrangements based on gender category (West and Zimmerman, 1987). Hochschild (1989) argues that where men's beliefs about relative gender power are threatened by wives' earning power, couples seek a balance by having the breadwinning wife do more domestic tasks regardless of the "logic of the pocketbook." Empirical support for this conjecture has been found in the United States (Brines, 1994) and Australia (Bittman et al., 2003): as wives become the primary breadwinners, they do more of the domestic tasks to reinforce traditional gender identities. The division of labour is part of the on-going negotiation process of marriage and can affect marital outcomes. Some models of the family contend that increases in women's labour force participation result in greater marital instability because of women's decreasing need for men's economic production (Becker, 1981, 1985) or increasing competition for occupational status (Parsons, 1953). Empirical evidence of the direct relationship between women's employment and marital instability, however, is mixed (Brines and Joyner, 1999; Bumpass, Martin, and Sweet, 1991; Hoffman and Duncan, 1995; Ruggles, 1997; South, 2001), or effects are contingent on other factors (Aberg, 2003; Schoen et al., 2002; South and Lloyd, 1995). In contrast, Oppenheimer $(1988,1997)$ argues that women's employment is now desirable for family economic flexibility. Sweeney (2002) found evidence that employed women in the U.S. are more likely to marry than unemployed women. Similarly, Moffitt (2000) reports that U.S. marriage rates have been declining at a faster rate among the least-educated women. In contrast, the greater income associated with more highlyeducated, dual-career couples appears to off-set any negative effects of more educated women's economic independence (Moffitt, 2000).

Gender is a cultural construct of sex roles, a definition of "Masculine" and "Feminine" and of the prerogatives of male and female. While culturally and historically -bound, gender commonly is a function of power relations and the social organization of inequality. Feminist scholars define gender as the social organization of sexual difference or a system of unequal relationships between the sexes. De Lauretis in 1987 has elaborated on the concept and the social fact of gender in the following way:

The cultural conceptions of male and female as two complementary yet mutually exclusive categories into which all human beings are placed constitute within each culture a gender system that correlates sex to cultural contents according to social values and hierarchies.

Black (1995) develops a model of employer discrimination in an equilibrium search model. In his model there are two types of worker, A and B who have identical marginal products and value of non market time. Workers receive utility from working both from the wages they receive and from job satisfaction. There are also two types of employers, non-discriminatory employers and discriminatory employers who have distaste for employing type B workers and therefore will never offer type B workers a job. Black shows that his model produces the standard results from search theory-workers form a reservation utility level that is a function of their utility from home production and their cost of search. Workers then sequentially search over jobs until the utility level from a job exceeds their reservation utility level. Black goes on to show that the presence of discriminatory employers lowers the reservation utility level of type B workers. This is because searching over the jobs with discriminatory employers is costly but offers no benefits since discriminatory employers will never employ a type B worker. This in turn implies that type B workers will accept a job with a lower utility level due to both lower wages and lower job satisfaction. Black also shows that the wages of type B workers will be lower even if the marginal employer has no taste for discrimination. Since all employers know that type B workers have a lower reservation utility level, they will use their market power (which exists in an equilibrium search model) to offer type B workers a lower wage. Black also shows that an increase in the number of discriminatory employers has an ambiguous effect on the length of search for type B workers relative to type A workers. This is because, while the higher fraction of prejudiced employers makes it harder for type B workers to find a nonprejudiced employer who is willing to employ them and therefore leads to more search, it also reduces the reservation level of utility for these workers which leads to less search. Therefore, the overall effect is ambiguous. 
Status of Women: Threats and opportunities

Table No. 1: Women employment and unemployment scenario in India:

\begin{tabular}{|c|c|c|c|}
\hline Employment Growth & 1983-1994 & 1994-2000 & $2000-2005$ \\
\hline \multicolumn{4}{|c|}{ Rural } \\
\hline Male & 1.93 & 0.80 & 2.20 \\
\hline Female & 1.37 & $\mathbf{0 . 0 3}$ & 3.61 \\
\hline Total & 1.73 & 0.51 & 2.70 \\
\hline \multicolumn{4}{|c|}{ Urban } \\
\hline Male & 3.23 & 2.86 & 3.28 \\
\hline Female & 3.78 & 1.50 & 5.41 \\
\hline Total & 3.34 & 2.58 & 3.71 \\
\hline \multicolumn{4}{|c|}{ Total } \\
\hline Male & 2.25 & 1.35 & 2.51 \\
\hline Female & 1.67 & 0.19 & 3.90 \\
\hline total & 2.06 & 0.98 & 2.95 \\
\hline
\end{tabular}

Source: NSSO Employment and Unemployment Survey Reports (year?)

From Table No.1 we found that there is a employment growth in case of Women compare to their counterpart specifically urban area.

Table No.-2: Average Daily wage (in Rs.) of regular and casual workers (15-59 years) 2004-2005

\begin{tabular}{|l|l|l|l|}
\hline & Male & Female & $\begin{array}{l}\text { Index of gender bias in wage } \\
\text { payment }\end{array}$ \\
\hline \multicolumn{5}{|c|}{ Regular } \\
\hline Rural & 144.93 & 85.53 & 0.59 \\
\hline Urban & 203.28 & 153.19 & 0.75 \\
\hline \multicolumn{5}{|c|}{ Casual } \\
\hline Rural & 55.03 & 34.94 & 0.63 \\
\hline Urban & 75.1 & 43.88 & 0.58 \\
\hline
\end{tabular}

Source: Employment report of GOI, 2010

In case of casual worker there is also gender biasness and they received low wages. From table No. 3 it has been found that gender bias in casual wage payment is low in rural areas (o.63) than in urban a reas (0.58). The opposite picture can be found in case of rural workers. According to Deaton and Dreze , (2002) rural casual labour constitutes the single largest segment of the total workforce in India. Among rural casual labourers, agricultural labourers occupy a predominant position. The rural agricultural wage rate hence is considered as one of the most robust indicators of economic well being not only of agricultural labourers but also of the overall rural population. The main point to discuss about what type jobs they chosen that means descent work. From different studies it has been found that gender relation plays a significant role in case of education, wealth and employment. In most societies women work longer hours than men when both paid and unpaid work are included and have lower earnings, low level of education and also less access to credit. Gender is considered the basis for division between "productive" and "reproductive" activities. The former refer to income-generating activities which are generally linked to markets while the latter relate to the care and development of people and capacity to work.

Table No.-3 Average wage earnings received per day by female casual labourers

\begin{tabular}{|l|l|l|}
\hline \multirow{2}{*}{} & Average wage earnings received per day by female casual labourers in \\
\cline { 2 - 3 } & $\mathbf{1 9 9 9 - 2 0 0 0}$ & $\mathbf{2 0 0 4 - 0 5}$ \\
\hline Rural & Rs. 29.01 (gender gap: Rs.15.83) & Rs. 36.15 (gender gap: Rs. 20.38) \\
\hline Urban & Rs. 37.71 (gender gap: Rs. 24.55) & Rs. 44.28 (gender gap: Rs. 31.23 ) \\
\hline
\end{tabular}

Source: NSSO survey

As per Census 2001, the work participation rate for females is 25.7 percent whereas that of males is 51.9 percent. As per Census 2001, Indian female population consists of 14.68 percent main workers, 10.95 
percent marginal workers and the remaining 74.37 percent non workers. As per the fifth Economic Census 2005, at all India level, percentage of total adult female workers in the total persons employed is 19.3 percent.

As per NSSO (2004-05), at all India level, the share of women in wage employment in non agricultural sector is 20.23 percent in 2004-05 vis-a- vis 16 percent in 1999-2000.

Table No.-4: Sex Ratio (number of females per 1000 males) -Census 1951-2001

\begin{tabular}{|l|l|l|l|}
\hline \multicolumn{5}{|c|}{ Sex ratio } & All India \\
\hline Year & Rural & Urban & 946 \\
\hline 1951 & 965 & 860 & 941 \\
\hline 1961 & 963 & 845 & 930 \\
\hline 1971 & 949 & 858 & 934 \\
\hline 1981 & 951 & 879 & 927 \\
\hline 1991 & 938 & 894 & 933 \\
\hline 2001 & 946 & 900 & \\
\hline
\end{tabular}

Source:Census Report

From the above table it has been found that sex ratio has been decreased from 965 in 1951 to 946 in 2001 in rural areas and in case of India sex ratio has declined from 946 in 1951 to 933 in 2001. But most significant point is that sex ratio in the urban area increased though it has been decreased but after 1971 it increased.

Table No.: 5:Work Participation Rates (WPR) by sex 1981 - 2001 (Census)

\begin{tabular}{|l|l|l|l|}
\hline Year & Female & Male (\%) & Persons (\%) \\
\hline $\mathbf{1 9 8 1}$ & 19.7 & 52.6 & 36.7 \\
\hline $\mathbf{1 9 9 1}$ & 22.3 & 51.6 & 37.5 \\
\hline $\mathbf{2 0 0 1}$ & 25.7 & 51.9 & 39.3 \\
\hline
\end{tabular}

Source:Census Report

Above table indicates that work participation rate is increased to 25.7 percent in 2001 from 19.7 percent in 1981 in case of female but in case of male work participation rate is decreased to 51.9 percent in 2001 from 52.6 percent in the year of 1981 .

Table No.-6: Population by work status- Census 2001

\begin{tabular}{|l|l|l|l|l|l|l|l|l|l|}
\hline & \multicolumn{3}{|c|}{ Main workers } & \multicolumn{3}{c|}{ Marginal Workers } & \multicolumn{3}{c|}{ Non workers } \\
\hline & Persons & Male & Female & $\begin{array}{l}\text { Person } \\
\text { s }\end{array}$ & Male & Female & Persons & Male & Female \\
\hline $\begin{array}{l}\text { All } \\
\text { India }\end{array}$ & $\begin{array}{l}3130.05 \\
(100 \%)\end{array}$ & 2401.48 & $\begin{array}{l}728.57 \\
(100 \%)\end{array}$ & 892.3 & 348.67 & 543.63 & 6263.76 & 2571.42 & 3692.33 \\
\hline Rural & $\begin{array}{l}2291.87 \\
(73.22 \%)\end{array}$ & 1691.01 & $\begin{array}{l}600.85 \\
(82.47 \%)\end{array}$ & 807.7 & 297.38 & 510.32 & 4325.35 & 1827.64 & 2497.71 \\
\hline $\begin{array}{l}\text { Urba } \\
\text { n }\end{array}$ & $\begin{array}{l}838.18 \\
(26.78 \%)\end{array}$ & 710.47 & $\begin{array}{l}127.72 \\
(17.53 \%)\end{array}$ & 84.6 & 51.29 & 33.31 & 1938.41 & 743.79 & 1194.62 \\
\hline
\end{tabular}

Source: Census, 2001

Table No. 7: Women Employment in organized sector (in lakh)

\begin{tabular}{|l|l|l|l|}
\hline & As on $\mathbf{3 1 / 3 / 2 0 0 4}$ & As on $\mathbf{3 1 / 3 / 2 0 0 5}$ & \% change \\
\hline Public & 28.9 & 29.21 & 1.07 \\
\hline Private & 20.44 & 20.95 & 2.5 \\
\hline Total & 49.34 & 50.16 & 1.66 \\
\hline
\end{tabular}

Source: M/o Labour \& Employment

(Organized sector consists of all public sector establishments and private non- agricultural establishments employing 10 or more workers)

In this table we found that 50.16 lakh women are employed in the organized sector consisting 58.23 percent in public sector and 41.77 percent in private sector in the year on 2005. 
Women and Development in India: An issue of marginalization of female labour

TableNo.8: Female employment in Central Government (Census of Central Government employees, DGET)

\begin{tabular}{|l|l|l|l|l|}
\hline Sr. No & \multicolumn{3}{|c|}{ Female employment } \\
\hline & Number (1991) & $\begin{array}{l}\text { Share to total } \\
\text { employment (\%) }\end{array}$ & Number (2001) & $\begin{array}{l}\text { Share to total } \\
\text { employment \%) }\end{array}$ \\
\hline Communications \& IT & 79740 & 12.02 & 75451 & 12.21 \\
\hline Railways & 61788 & 3.73 & 70030 & 4.63 \\
\hline Defence (Civilian) & 36412 & 6.92 & 53132 & 9.01 \\
\hline Others & 11059 & 11.98 & 93187 & 8.06 \\
\hline Total & 288999 & 7.58 & 291800 & 7.53 \\
\hline
\end{tabular}

Source: Census, 1991 and 2001

From this table we found that female employment has decreased from 7.58 percent in 1991 to 7.53 percent in 2001 in case of employment in Central Government. Different studies clearly indicate that women participation in labour is less than their counterpart. According to the social identity theory, attitudes towards an individual are shaped by his or her membership in a social group and evaluation of one's groups in social comparison to specific other groups in terms of gender, race, class occupation etc. This is the key source of ingroup identification. So an individual when considered them the member of a group then he or she tried to develop and maintain a positive identity of their in- group in contrast to the out-group. One's own social identity is a factor which may affect the perception of discrimination. From different studies it has been found that there is a positive relationship between social identities and perceived of discrimination.

Table No.9: Literacy rates, 1951-2001 (Census)

\begin{tabular}{|l|l|l|l|l|}
\hline Census year & Person (\%) & Male (\%) & Female (\%) & $\begin{array}{l}\text { Male -female gap } \\
(\boldsymbol{\%})\end{array}$ \\
\hline $\mathbf{1 9 5 1}^{*}$ & 18.3 & 27.2 & 8.9 & 18.3 \\
\hline $\mathbf{1 9 6 1}^{*}$ & 28.3 & 40.4 & 15.4 & 25.1 \\
\hline $\mathbf{1 9 7 1}^{*}$ & 34.5 & 46.0 & 22.0 & 24.0 \\
\hline $\mathbf{1 9 8 1}^{*} *$ & 43.6 & 56.4 & 29.8 & 26.6 \\
\hline $\mathbf{1 9 9 1}_{*}^{*}$ & 52.2 & 64.1 & 39.3 & 24.8 \\
\hline $\mathbf{2 0 0 1} *$ & 64.8 & 75.3 & 53.7 & 21.6 \\
\hline
\end{tabular}

*aged 5+, ** aged 7+

Source :Census of India(year?)

Table No. 9 is showing that male-female gap in case of literacy is a decreasing trend for the last two decades. Globalisation and technological development creates) windows of opportunities in front of women. So the most important question is to find out the opportunities and make women more strong in terms of economic equality not be identified as future burden.

\section{Conclusion:}

Now- a-days gender discrimination is still an important issue for every organization because individuals reporting that they perceive discrimination based on gender in the workplace. From different studies it has been found that women perceive more gender discrimination (Gutek, Cohen, \& Tsui, 1996). Women perceive more gender discrimination than do men, and these perceptions are associated with lower feelings of power and prestige on the job, more work conflict, more hours spent on paid work activities, and a lessened willingness to make the same career choices (Gutek et al., 1996). Perceived gender bias against women is also an important issue as it relates to equal employment opportunities. It is very difficult to define women empowerment using a single criterion because it is very much associated with multifaceted facts and dimensions. It is doubtless to comment that the women have already come out from the molluscan shell and kept her footprint on every nook and corner of society. But they still lack access to equality. In this case the quality of the employment should be addressed. For a specific time period for a particular society the relationship between men and women regulated by the sum of social norms, conventions and practices. Because of globalisation women have gained opportunities in case of employment. But there is no evidence that they enhance their capability to negotiate better wage and better working conditions. 


\section{References:}

[1] Agarwal,Bina(1986) “Women poverty and Agricultural Growth in India” in the Journal of Peasant studies Vol.13. No. 4 July 1987

[2] Anker ,R (1998), " Gender and Jobs : Sex segregation of occupations in the world,ILO,Geneva

[3] Dandekar, V.M.. (1982): 'Integration of Women in Economic Development', Economic and Political Weekly, Oct 30th, 1982, pp1762-1786.

[4] Deshpande and Deshpande (1998): 'Impact of Liberalisation on Labour Market in India: What do Facts from NSSO's 50th Round Show?' Economic and Political Weekly, Vol XXXIII, No 22, May 30-June 5.

[5] Hirway, Indira (2002): 'Employment and unemployment situation in the 1990's: How good are the NSS data?', Economic and Political Weekly, May 25th, 2002

[6] Lim, Linda. 1990. "Women's work in export factories: The politics of a cause", in Tinker, Irene (ed.), Persistent inequalities. Oxford: Oxford University Press.

[7] Mendoza, Ronald. 2003. "The multilateral trade regime: A global public good for all?", in Kaul, Inge, Conceição, Pedro, le Goulven, Katell, and Mendoza, Ronald (eds.), Providing global publicgoods: Managing globalization. New York, Oxford University Press

[8] Sen, Gita and Chiranjib Sen (1985): 'Women's Domestic Work and Economic Activity: Results from National Sample Survey', Economic and Political Weekly, April 27th, 1985. pp.WS49-WS55.

[9] Sundaram, K (2001b): 'Employment and Poverty in India in the Nineteen Nineties: Further Results From NSS 55th Round Employment-Unemployment Survey, 1999-2000', paper presented at the International Seminar on 'Understanding Socio-Economic Changes through National Surveys' Organised by the National Sample Survey Organisation, May 12-13, New Delhi.

[10] Sundaram, K (2001a): 'Employment -Unemployment Situation in the Nineties: Some Results from NSS 55th Round Survey', Economic and Political Weekly, March,17 